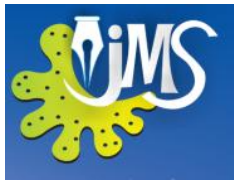

\title{
Meeting the Challenge of Accessibility and Utilization of Modern Instructional Materials in Rural Secondary Schools in Nigeria
}

\author{
Amali Onche \\ Department of Social Sciences Education \\ Faculty of Education, University of Ilorin, Nigeria
}

\begin{abstract}
The world is now globalised by means of information and communication technology (I.C.T). Education has played and will continue to play a crucial role in this process by means of teaching and learning processes. Paradoxically, ICT has also increased the gap between the knowledge and living standard in the lives of the persons in urban and rural areas across Nigeria and the world. This paper examines the plight of rural secondary schools in Nigeria towards access to modern instructional materials. It addresses the problems of lack of or inadequacy of modern instructional materials for use in Nigeria rural secondary schools in relation to social equity and educational opportunities for individuals, society and the Nigeria nation. It examines its implications and proffers solutions and recommendations towards ameliorating the problems of lack of or inadequacy of modern instructional materials for use in the rural secondary schools across Nigeria.
\end{abstract}

KYWORDS: Krill Meeting the Challenge, Accessibility and Utilization, Modern Instructional Materials, Information and Communication Technology (ICT), Rural Secondary Schools 


\section{INTRODUCTION}

\section{THEORETICAL APPROACH:}

As we are in a new millennium, there is an increased awareness of the need to use modern scientific approach in teaching and learning processes in our schools. At present, there is a universal recognition of information and communication technology as a major force in the dissemination of knowledge (Aina, 2013). Nigeria has been at integrating I.C.T. into education and other sectors. She still has a great deal of instructional and administrative work in secondary schools carried out manually. The condition is worse at the rural level. In an attempt to keep pace with development in computer education, Nigeria enacted a policy on computer education. According to the National Bureau of Statistics (FGN, 2006), the plan was to establish pilot schools and there-after diffuse the innovation first to "all" secondary schools and then to primary schools. Unfortunately, beyond the distribution and installation of computer in Federal Government Colleges (FGCs), the project did not really take off before it was grounded.

Lack of exposure and limited accessibility to modern instructional facilities is a major problem of secondary schools in the rural areas of Nigeria. These have consequential negative effects on the academic standard of the schools in those areas. It may be a major factor responsible for poor performance of the students. The turnout of inefficient products of secondary schools from the rural areas may not be unconnected with it. Poor academic performance leads to end point for the pursuit of further education among students in the rural areas of Nigeria. This paper, thus examines the promotion and utilization of modern instructional materials in Nigeria rural secondary schools in relation to the effects of access to modern instructional materials and proffer ways forward to ameliorate the condition since education is a tool for social mobility, integration and national development as expressed in the National Policy on Education (FGN, 2004).

Secondary education is noted by If enk we (2013) and in the National Policy on Education (FGN, 2004) as the stage where children receive primary education and before the tertiary stage. It is noted to be a comprehensive type of education where its broad goals are to prepare children who have completed primary education to have opportunity for education to a higher level, irrespective of sex, social status, religion or ethnic background. The constitution of the Federal Republic of Nigeria in section 18(1) states that "Government shall direct its policy towards ensuring that there are equal and adequate educational opportunities at all levels" (FGN, 1999). This has led to Government policies in the creation of Universal Primary Education Scheme (1977) and the Universal Basic Education Scheme (FGN, 2004) and laying emphasis on the implementation of Millennium Development Goals (MDOGs) of the United Nation (U.N). This implies that planning and provision for transfer of skills, knowledge and the information seeking capacity of individual learners and those in the rural areas must be supported, motivated and provided evenly across the length and breadth of Nigeria.

At the global level, the United Nation (U.N) has made "Education for All" a requirement for all nations. This translates into 
opportunities for all to have access to education regardless of gender, race, ability or disability and geographical location. This presupposes that the provision and distribution of education, educational resources and materials must be impartial, regardless of geographical locations. In this respect, by implication the secondary schools in the rural areas of Nigeria ought to have equal access to modern instructional materials like others in urban or metropolitan areas.

Social equity in educational opportunities in Nigeria allows individuals to participate in every sphere of life endeavors. It should not have constraining effects of sociocultural, religious, political, economic and geographic impediments. It also includes the recognition and respect for the rights of every citizen, irrespective of ethnicity, language, religion, gender or other social attributes, to have equal rights, obligation and opportunities to education. In this context, the activities of teachers, government or other agencies must not be in contradiction to exhortations on national access in classroom interaction across the country. For instance, all forms of discrimination in provision of educational facilities should be discouraged.

Further, the Nigerian constitution (FGN, 1999) provides for the protection of the rights of all persons in the allocation of resources (politically, socially, educationally and economically). Incorporating the principles of Federal character in section (4) requires every government body at every tier of the federation in their composition and activities to promote a sense of belonging and loyalty among all peoples of the federation. This suggests that the events inside or outside the classroom should not be an exception, especially in the allocation of educational resources.

\section{THE IMPORTANCE OF INSTRUCTIONAL MATERIALS TO RURAL SECONDARY SCHOOLS}

Instructional materials include the use of information and communication technology (I.C.T.) which has become an indispensable phenomenon in the new millennium. It is like a right of all persons, irrespective of geographical location to have access to I.C.T. It is imperative to live-long value and is used to boost the quality of education. All persons who seek knowledge irrespective of differences in language, culture, gender and location desire to have access to it. Aina (2013) noted its potentials to accelerate motivate, improve the teaching and learning processes. It promotes pedagogical activities, research work for students and teachers, (especially the use of emails, mailing lists, chat-rooms, calculators, viewing centre's, and interaction). It also encourages social process that facilitates collaboration among learners and teachers both in rural, urban and at the global levels (Daramola, 2008).

The use of instructional materials such as educational films, plays and drama when screened and played in rural schools can help in building national integration and awareness. Radio talks, television shows and lessons can encourage students to witness and participate in activities outside their domain (Aina, 2013). Therefore marginalizing the rural schools access to such modern instructional materials is travesty on their fundamental rights and negates the principles of social equity and equal educational opportunities. 


\section{CHALLENGES OF ACCESSIBILITY AND UTILIZATION IN RURAL SECONDARY SCHOOLS}

By exegesis of correlation, rural secondary schools in Nigeria are the schools that are situated in the rural areas of the country. They are influenced by lack of support of cultural innovation with little or no social change. They also stand discouraged in comparison to the urban secondary schools in the provision and application of instructional modern equipment's.

The life style of rural dwellers affects the teachers and learners and few activities that characterize school system. Their life style equally influence their responses to a wide range of school activities especially those programmes that fit into teaching and learning processes. These may influence the ability of learners in the rural areas to respond to the overall school activities. Denial of modern instructional materials makes things worse for them. By extension, realization of normative order in the school environment relies greatly on the social and intellectual qualities of the teacher (Bauman, 2000).

The life of the rural teachers tend to be remote towards acquisition of new ideas, skills and knowledge by failure in enrolling for further educational programmes including Information and Communication Technology (ICT). With this, the academic and intellectual capacities of teachers and learners are bound to be affected substantially during classroom interaction. It is improved technology that can allow teachers and learners in the rural secondary schools to keep abreast of the latest ideas around the world.
School buildings do not only represent one of the physical elements of civilizational change, but the knowledge, ideas, skills, values and beliefs which are transmitted to the learners can also influence cultural change (Bauman, 2000). These are in the form of human relationship, social stratification and mobility which can be engineered through adequate and the necessary provision of instructional resources to the rural secondary schools. Thus the effective use of instructional materials by the teachers is likely to serve as a tool for social change in the rural community.

The implication for the rural school is that, the advancement in educational technology has been erratic and unplanned. The residual effects on the rural secondary schools and their product are that they cannot cope with the modern direction of instructional materials and other soft ware's now available for use in schools. This compounds further challenges as education has become a competitive enterprise where the urge for further education and social mobility is increasing by day. It would require their exposure to the exegesis of academic tests and examination for which they are not properly prepared. This has often been the case for the poor performance and output of students from Nigeria rural secondary schools. The challenge is enormous and the response should be urgent. The required condition in Nigeria now is a compulsory knowledge of the use of computer by all students in our secondary schools this is with the hope of catching up with the technological skills of the millennium. It is a stringent condition. This is because the condition imposed requires the students from the rural secondary schools to face the challenges without adequate exposure to the training and skills in computer education. 
Besides, Nigeria Government is yet to meet the international requirement of funding education (proportionately) with her national income budget. The United Nation (U.N) standard is said to be $26 \%$ of national income (Obasi, 2008). In Nigeria, less than $12 \%$ is devoted to education. This is meager and constitutes problem of funding instructional materials which require a huge capital investment. The financial base of the rural secondary schools are often weak as they are financially cash striped and cannot on their own budget for huge capital ventures without government support. National Board of Statistics (NBS) has shown that there are huge gaps between the provision of instructional materials in the rural and urban secondary schools by the Federal, State, Local Government and the other educational agencies (Obasi, 2008).

The rural secondary schools in Nigeria have no access to electricity and lack other means of power generation. In Nigeria, power generation is still a major problem of the rural dwellers as infrastructural developments of most rural schools are at its lowest ebb. Thus, there are wide gaps in the provision of the basic educational resources between the rural secondary schools and the ones located in the cities in Nigeria. The challenges are many. Asanya (2005), Ighodora (2008) and Kpolovie and Esezi (2013) noted some of the challenges to be included among others are the following:

1) According to Aduwa-Ogiegbaen and Iyanu (2005) environmental realities are difficult to manage because fans, sealed rooms and stable electricity are lacking in many urban areas and worse in the rural areas of Nigeria. Infrastructural deficiencies such as lack of steady power generation which is even worse in the rural areas of the country.

2) Cost effect of information and communication technology (ICT). The price of modern instructional materials such as computer is several times higher in Nigeria than what it costs in more advanced countries. Besides only few schools are equipped with good classrooms, studios with T.V. and computer instructional facilities. Other instructional materials such as the printers, monitors, projector, papers, disc drives, modern chalk board etc are

3) Beyond the reach of rural secondary schools.

4) There is also the problem of skilled teachers in the field of Information and Communication Technology. Where there are skilled teachers, other problems naturally include problem of installation, maintenance, operation, network administration and local technicians to service or repair these equipment's and the other facilities. In most of the rural secondary schools, most of the facilities are non-existent, hence the traditional chalk and duster approach still dominates in secondary school pedagogy (Obasi, 2008).

5) There are very few internet providers that provide gateway services to Nigerian users. Nigerian providers are often in partnership with foreign communication companies who usually provide poor services to Nigerian customers and often exploit and 
defraud them. Others charge high fees, thus limiting access to the use of the internet. In rural areas of Nigeria, they are nonexistent.

6) Government's Policy towards efficient provision of these aspects of educational resources has not been encouraging and has always not been well planned, monitored, supervised and evaluated with rural schools as the back bench of implication of these policies.

7) The socio-economic status of the rural dwellers of Nigeria who are predominately peasant farmers who cannot afford the funding of education of their children makes secondary school students indigent in accessing instructional materials for their personal study. The teachers too are poorly paid in Nigeria and therefore cannot venture into self-sponsorship to acquire new skills.

\section{MEETING THE CHALLENGE}

Any recommendation and suggestion that would involve the promotion and utilization of modern instructional materials should take cognizance of the principle of social equity in educational opportunities. For Nigerian rural secondary schools, there should be a consideration of the social context of their locales. The following suggestions are thus raised to combat the problems faced by rural secondary schools in Nigeria.

1) Every community in the country is aware of the ethno-regional basis of political development which creates room for political power. Education is a catalyst to achieving such objectives. Discrimination in rights and privileges in the distribution of social amenities for educational purposes should be a matter for grave concern because it leads to marginalization from social, economic and political opportunities of the rural inhabitants in Nigeria.

2) There cannot be unity in diversity through education if the gap in providing educational resources in Nigeria is allowed to widen between the rural and urban areas. This will emasculate the idea of social equity in educational opportunities for all (Obasi, 2008). There is therefore the need to address the fears of the rural students who face the fierceness of educational competition, such as NECO, S.S.C.E., Jamb and the intrigues, the betrayal and the domination for equal educational opportunities to tertiary institutions in the country. There should be functional approach to fill the gap created by discrimination in the distribution of educational resources because they are instrumental to the success or failure of the rural secondary school students in Nigeria. Paradoxically, diversity and integration are two contradictory realities which Nigeria must reconcile if the country must achieve nonfetishistic, non-emblematic and collective success in education (Obasi, 2008). There is need to fill the widened gap that exists in the provision of instructional resources for teaching and learning of the different school types and locations across the country. 
3) There must be instructional technology centres in all schools where teachers and students can use for effective dissemination of knowledge. The provision of educational technology in the rural secondary schools will no doubt directly improve the quality of education for the young people of the country.

4) There should be no discrimination in the provision of instructional resources for all secondary schools in the country. Teaching and learning exercise should be part of total commitment of Government and should be tied to provision of instructional materials. This is because they have societal and individual values as they help in the cognitive development of learners and the effectiveness of the teachers both in the rural and urban areas of the country.

5) The life of the rural secondary school teachers should be improved and oriented toward the acquisition of new ideas, skills and knowledge by enrolling them for further educational programmes that require the use of modern instructional equipment's. Teachers' academic and intellectual capacities when improved are bound to profit substantially in classroom interaction of the students in the rural areas of Nigeria.

6) Funding is crucial in all respect to the above, therefore there is need for national consciousness for continuous increase in national budgets on education to facilitate the provision of the essential instructional materials for our secondary schools. This will also cater for the welfare of all personnel involved in the running of our secondary schools across the country.

7) The policy of investment and privatization of education should place more emphasis on the development of rural schools in Nigeria. This should include equipping the schools appropriately and adequately to enable them cope with the modern trend in teaching and learning. Further, the Nigerian nation stands to gain, if we begin investment on education from developing it from the rural areas. The private entrepreneurs should be encouraged towards this direction as well. This will promote the provision and utilization of modern instructional materials in the rural secondary schools.

MARGINALIZING THE INSTITUTIONS IN THE RURAL AREAS IN THE PROVISION OF INSTRUCTIONAL MATERIALS SHOULD BE DISCOURAGED IN ORDER TO BRING EDUCATION CLOSER TO THE PEOPLE AND TO EXPOSE THEM TO NEW KNOWLEDGE AND SKILLS AS WELL AS TO IMPROVE THEIR WELLBEING IN KEEPING WITH THE DEMOCRATIC PRINCIPLES OF SOCIAL EQUITY AND EDUCATIONAL OPPORTUNITIES FOR ALL (FGN, 2004).

\section{CONCLUSION}

The onus of taking Nigeria out of the woods in the new millennium lies in effective teaching and learning processes. This requires a commitment to civic culture of the modern 
times which are rooted in modern instructional materials. Emphasis should be on developmental decision-making bodies and policy formulators in the country to consider the place of instructional materials as a powerful mechanism for bridging the educational gap within the rural and urban secondary schools in Nigeria. At present, the quality of teaching in the rural schools is endangered and the quality of learning is distorted as well (Abdulazeez, 2008). The promotion of social equity and educational opportunities to create access to instructional materials will no doubt help to improve the discrepancies witnessed in the academic performance of the rural secondary schools in Nigeria and the life style of Nigerian rural dwellers.

\section{REFERENCES}

ABDULAZEEZ, Y. (2008). Urban social life styles and school activities in Africa: Evidence from Nigeria". Being a text of paper presented at the $2^{\text {nd }}$ National Conference Organized by National Association of Sociologists of Education (NASE), University of Nigeria Nsuka $\left(14^{\text {th }}\right.$ $-18^{\text {th }}$ October, 2008)

AINA, L. O. (2013). Information, knowledge and the gatekeepers. The One Hundred and Thirty-Second Inaugural Lecture delivered at the University of Ilorin, $16^{\text {th }}$ May, 2013.

ASANYA, P. (2005). Computer science in secondary schools. Benin:Udodoumen Publisher.

BAUMAN, Z. (2002). Liquid modernity. Cambridge: Cambridge Press.

DARAMOLA, C.O. (2008). Teaching and learning in urban society: The imperative of information and communication technology. Being a paper presented at the $2^{\text {nd }}$ National Conference Organized by National Association of Sociologists of Education (NASE), University of Nigeria Nsuka $\left(14^{\text {th }}-18^{\text {th }}\right.$ October, 2008).

FGN : FEDERAL GOVERNMENT OF NIGERIA(1999). Constitution of the federal republic of Nigeria 1999. Lagos:

Federal Government Press.

FEDERAL GOVERNMENT OF NIGERIA (2004). National policy on education. Lagos: Federal Ministry of Education.

FEDERAL GOVERNMENT OF NIGERIA (2006). National bureau of statistics annual abstracts of statistics 2006. Abuja: National Bureau of Statistics.

IGHODARO, O.K. (2008). Problems and prospects of using information and communication technology (ICT) in secondary schools in Oredo Local Government, Edo State. Unpublished research project of the Department of Arts and Social Sciences Education, University of Ilorin.

KPOLOVIE, P. J. \& ESEZI, I. O. (2013). Adequacy-inadequacy: Education funding in Nigeria. Universal Journal of Education and General Studies, v. 2 no. 8 pp. 239 - 254. Retrieved from http://www.universalresearchjournals. org/ujegs

OBASI, E. (2008). Challenges for secondary education in the culturally diverse Nigerian society. Being text of lead paper at the National Association of Sociologists of Education (NASE) conference holding at the University of Nigeria Nsuka $\left(14^{\text {th }}-18^{\text {th }}\right.$ October, 2008).

ADUWA-OGIEGBAEN, S. E. \&IYANU, E. O. S. (2005). Using information and 
communication technology (ICT) in secondary schools in Nigeria. Journal of Educational Technology and Society, v. 8 pp.104- 112.

UNITED NATION DEVELOPMENT PROGRAMME (2004). Human development report (2004): Cultural liberty in today's diverse world. New York: United Nation Development Programme.

YUSUF, M. (2005). Information and communication technology and education: Analysing the Nigerian natural policy for information technology. International Education Journal, v. 6. pp. 316-321. 
